\title{
Examining Science Process Skills Tests: A Case of Turkey
}

\author{
Okan Sibic (iD) 1,*, Burcin Acar Sesen (DD 1
}

${ }^{1}$ İstanbul University-Cerrahpaşa, Hasan Ali Yücel Faculty of Education, Department of Mathematics and Science Education, Science Education, Turkiye

ARTICLE HISTORY

Received: Feb. 26, 2021

Revised: Nov. 28, 2021

Accepted: Jan. 13, 2022

Keywords:

Graduate theses in science education,

Science process skills, Meta-synthesis study.

\begin{abstract}
One of the main goals of science education is to make students gain science process skills. Thus, it is significant to measure whether students gain those skills or not. For this purpose, various tests have been produced and used in various studies. This study aims to examine science process skills tests which have been used in the theses produced in the field of science education from the perspectives of the originality, question types used, and the science process skills measured in the tests, and the number of questions for each measured science process skill. Within the scope of this meta-synthesis study, 82 master's theses and 34 doctoral dissertations from Turkey were analyzed. The findings indicate that science process skills were measured with multiple-choice tests, and only in smaller number of studies, original tests were developed for the corresponding study. It was also discovered that some science process skills were measured more frequently than others. As a result of the study, some suggestions were provided.
\end{abstract}

\section{INTRODUCTION}

In the last decades, there have been rapid development and changes in science and technology to make life easier. In order to keep up-to-date, countries revise their educational programs, including their science programs, continuously. Similarly, educational programs were reviewed in Turkey to be able to catch up with the recent trends in the world, and various changes were made so as to fulfil new necessities. Thus, the science curriculum in Turkey was revised to keep up with the rapid developments in science and technology in 2018 (Ministry of National Education, 2018).

The aim of the revised science curriculum of Turkey is to make students obtain basic knowledge and skills about science and engineering applications, to teach students nature-human interactions and to make them able to produce solutions towards the problems that occur as a result of nature-human interactions by benefiting from science process skills, to raise consciousness about sustainable development in students, to make students obtain knowledge and ability to use science process skills towards everyday life problems that they might be confronted, to help students develop science career knowledge, to teach students how scientists produce scientific knowledge and help them develop the science process skills in order to produce scientific knowledge, to emphasize the importance of reliability and validity in scientific studies, to help students develop interest and positive attitudes towards the nature, to

\footnotetext{
*CONTACT: Okan SIBIÇ $\bigotimes$ okan.sibic@iuc.edu.tr $\equiv$ İstanbul University-Cerrahpaşa, Hasan Ali Yücel
} Faculty of Education, Department of Mathematics and Science Education, Science Education, Turkiye 
emphasize the socio-scientific issues and by using such issues, to help students develop scientific reasoning skills, habit of scientific thought, and decision-making skills (Ministry of National Education, 2018). Additionally, it is possible to say that with the success of the new program, students will be curious and sensitive about the events and problems they confront in their surroundings and about the solution of the problems, and they will behave like a scientist. In the new program, it is realized the development and use of science process skills are emphasized frequently.

Science process skills (SPSs) are defined as the process skills that scientists practise during scientific knowledge (Aslan et al., 2016; Temiz \& Tan 2013). On the other hand, in the literature, it is possible to find some other definitions of SPSs. Ostlund (1992) and Charleswoth and Lind (2012) defined SPSs as skills which are used during the production of scientific knowledge, regulating the produced knowledge and also analyzing and solving the problems occurred in the process of producing scientific knowledge. In a similar vein, Anagün and Yaşar (2009) define SPSs as thinking skills used during the production of scientific knowledge and reasoning skills used about problems occurred during the process of producing scientific knowledge. Çepni et al. (1997) emphasized SPSs as some basic skills which make students active during learning by placing them into the center of learning and make learning easy and permanent and lead students to take responsibilities of their own learning. In addition to that, they emphasized that SPSs are the skills used in science laboratories and laboratory approach (Çepni et al., 1997). American Association for the Advancement of Science (AAAS) (AAAS, 1993) defines SPSs as the skills used during the production of scientific knowledge and behaviors, which are accepted in most of the science disciplines (Tan \& Temiz, 2003). When all the definitions are analyzed, it is observed that although there are some differences between them, they generally emphasize the same points.

In the literature, there are different studies which explain SPSs. Although there are some differences, all the studies point out the same skills as science process skills (Aslan et al., 2016). When the studies examined, it is observed that SPSs are generally divided into one group, two groups or three groups. For instance, Rezba et al. (2007) divided SPSs into two categories: basic SPSs and integrated SPSs. While the skills of observing, communicating, classifying, measuring metrically, inferring and predicting are basic SPSs, the skills of identifying variables, constructing a table of data, constructing a graph, describing relationships between variables, defining relationships between variables, acquiring and processing your own data, analyzing investigations, constructing hypotheses, defining variables operationally, designing experiments are included in integrated SPSs (Rezba et al., 2007). On the other hand, SPSs such as observing, classifying, measuring, finding space and time relationship, using numbers, prediction, inferring, communicating, making operational definition, defining and controlling the definitions, formulating hypothesis, making experiments, interpreting data, and creating models are included into one group named as science process skills by AAAS (AAAS, 1993). Çepni et al. (1997) grouped 13 SPSs into different categories at the end of the project undertaken by the Council of Higher Education/World Bank Development of National Education in 1997. In this study, the last classification of SPSs was considered. According to this classification, while observing, classifying, measuring, and finding space and time relationships are taken into basic SPSs group, making predictions, determining variables, interpreting data and inferring are handled in causal SPSs group. In the third group, which is experimental process skills, formulating a hypothesis, using data and formulating models, designing-making experiments, controlling variables and decision-making were included by the researchers. While Çepni et al. (1997) emphasized the importance of bringing students basic SPSs, they also pointed out that bringing students basic SPSs also makes it easier for them to develop higher order thinking skills. Additionally, Çepni et al. (1997) point out that causal SPSs comprise the skills used in the process of testing hypothesis and skills that are used until making 
logical results after testable studies. On the other hand, experimental SPSs are defined as complicated, versatile, requiring higher order thinking skills, which contains one or more basic process skills (Çepni et al., 1997).

In order to develop scientific knowledge, as a scientist would do, SPSs are important practical skills (Ondowo \& Indoshi, 2013), and have an important role while students are producing scientific knowledge and learning the nature of science directly (Erkol \& Ugulu, 2014). Therefore, it is important to measure whether students gain those skills or not. To do that, different tests have been produced in the literature. Among those tests, today, the most frequently used one is the SPS tests developed by Burns et al. (1985). In this test, there are thirty-six multiple-choice questions, and five different process skills are measured through those questions. The process skills measured are determining variables, formulating hypothesis, making operational definition, and interpreting data and graphs. The adaptation study of this test to Turkish was conducted by Geban et al. (1992). It is possible to encounter different SPSs tests in the literature apart from this test (for example Enger \& Yager, 1998; Smith \& Welliver, 1994; Temiz, 2001; Tobin \& Capie, 1981). In addition to all those tests, it is possible to say that in some studies, different SPSs tests were developed by considering the aim, sample, subject area, etc. In Turkey, for example, Daşdemir (2012), Demirörs (2018), Gültekin (2018), and Tatar (2006) developed new SPSs tests to measure students' gains towards SPSs. When the features of the SPSs tests were examined, it is possible to say that most of the tests were developed at primary levels and in science education. However, there were also some tests which were developed at secondary levels (9-11), e.g., Kazeni (2005). Burns et al. (1985) also developed their tests at primary and secondary levels (7-12).

Because SPSs are the skills that scientists use to reach scientific knowledge, they are standing out to as the skills which students should gain those skills under the scope of science education. At that point, the importance of bringing students the ability to use science process skills are emphasized in the new science education curriculum frequently as in the previous curriculum and different studies have been conducted to bring those skills to students. Additionally, different SPSs tests to measure whether the students were brought science process skills or not been observed in the literature.

This study aims to examine the SPSs tests used in the master's theses and doctoral dissertations (graduate theses) done in Turkey in the science education area from the perspectives of the originality of the tests, the question types, the SPSs measured, the number of questions of measured SPSs. The research questions of the study are as follows:

1. How is the distribution of originality of the SPS tests in graduate theses dissertations prepared in science education study area in Turkey?

2. How is the distribution of the question types (multiple-choice, open-ended, etc.) of the SPS tests in graduate theses prepared in science education study area in Turkey?

3. Which and to what frequency are the science process skills in SPS tests in graduate theses prepared in science education study area in Turkey measured?

\section{METHOD}

A meta-synthesis study which is also known as thematic content analysis method (Walsh \& Downe, 2005) was conducted in the present study. Meta-synthesis study is a methodology in which qualitative and quantitative studies are used together. In meta-synthesis studies, qualitative and quantitative studies are used as data or unit of analysis. Meta-synthesis studies are principally "concerned with understanding and describing key points and themes contained within a research literature on a given topic" (Bair, 1999, p. 4). To follow a meta-synthesis study, the required steps were explained by Walsh and Downe (2005) as follows:

1. Determining the appropriate studies 
2. Searching and evaluating the studies

3. Conceptualizing and comparing the studies

4. Synthesizing and reporting the findings.

In the theses -both master and doctoral- prepared in Turkey, SPSs tests were used widely. Therefore, in this study, in accordance with the definition of meta-synthesis studies, the SPSs used in the master and doctoral theses were examined from the perspectives of test style and type; the type of items of the tests; which process skills were measured, how many questions were used to measure each process skills; and the originality of the test, whether they were originally developed or adapted.

\subsection{Criteria for Constructing the Sample of the Study}

In the present study, in line with the aim of the study, the SPS tests were obtained from the master and doctoral theses published in Turkey between 2000-2019. To obtain the theses which contain SPS tests, 'Council of Higher Education Thesis Center' was used by the researchers. On the database, by typing 'bilimsel süreç becerileri' (Turkish translation of science process skills) keyword, detailed scanning was made, and 188 theses studies were reached. Firstly, all of the studies were reviewed in general and 69 out of 188 studies were decided as not compatible with the aim of the study. In Table 1, the reasons for excluding the studies from the sample were represented in terms of frequencies and percentage.

Table 1. Reasons for excluding studies.

\begin{tabular}{lcc}
\hline Situation & Frequency & Percentage (\%) \\
\hline The sample of the studies not appropriate & 26 & 37.68 \\
Not contain SPS test & 22 & 31.88 \\
Not open to access & 13 & 18.84 \\
Not provide any information about SPS tests & 8 & 11.59 \\
Total & 69 & 100 \\
\hline
\end{tabular}

As presented in Table 1,37.68\% of the theses were not included in the study since the sample of these studies comprise preschool or elementary school students and $31.88 \%$ of the studies were not included in the sample since they did not have any SPS tests. Since $18.84 \%$ of them do not have open access and $11.59 \%$ of them do not have any information about the SPS tests which were used, those studies were not also included into the sample of the study.

After examining the theses, 116 of them were included in the examination. While $29.32 \%$ of the theses found were doctoral dissertations, it was determined that $70.68 \%$ were master's theses. In Table 2, distribution by years of the theses studies was presented in detail.

Table 2. Distrubution by years.

\begin{tabular}{llll}
\hline Year & Thesis ID & Frequency & Percentage \\
\hline 2001 & T1 & 1 & 0.86 \\
2006 & T2, T3 & 2 & 1.72 \\
2007 & T4-T7; T83-T86 & 8 & 6.89 \\
2008 & T8-T15; T87, T88 & 10 & 8.62 \\
2009 & T16-T21; T89-T94 & 12 & 10.34 \\
2010 & T22-T26; T95-T98 & 9 & 7.75 \\
2011 & T27-T38; T99-T101 & 15 & 12.93 \\
2012 & T39-T50; T102, T103 & 14 & 12.06 \\
\hline
\end{tabular}




\begin{tabular}{llll}
\hline Table 2. Continued & & \\
\hline 2013 & T51-T62; T104-T107 & 16 & 13.79 \\
2014 & T63-T67; T108-T112 & 10 & 8.62 \\
2015 & T68-T73; T113 & 7 & 6.03 \\
2016 & T74-T78; T114-116 & 8 & 6.89 \\
2017 & T79-T81 & 3 & 2.58 \\
2018 & T82 & 1 & 0.86 \\
Total & & 116 & 100 \\
\hline
\end{tabular}

In Table 2, it is presented that SPS tests were started to be used in 2001, however, after this year, no study in which SPS tests were used was found until 2006. After 2006, it was observed that the interests towards SPS tests increased in the studies and between 2011-2013, SPS tests were included frequently in the theses. Besides, after 2006, SPS tests were included in at least one of the theses every year.

\subsection{Data Collection}

In the present study, an evaluation form which was prepared by the researchers in consistence with the aim of study was used as a data collection tool. The form, through which the features of SPS tests in graduate theses were determined, is presented in the 'Appendix' Section. The form was prepared by considering the SPSs stated as a result of the project of the Council of Higher Education/World Bank Development of National Education. Every SPS of the tests used in the theses was examined in detail and question numbers for each process skills were recorded in the corresponding form as data. In the cases in which different SPSs were observed except determining before (used for the first time), a new column was added to the right of the table, and new process skills were shown in the table to include those process skills.

\subsection{Data Analysis}

In the present study, to analyze the data, SPS tests were subjected to the content analysis technique. The SPS tests placed in the master's theses and doctoral dissertations were examined from the perspectives of what kind of tests they are (adaptation, original, etc.), type of test questions (open-ended, multiple-choice, etc.), the process skills measured, and the question numbers for each process skill; and all the findings were represented in different tables. All the SPS tests were included in the analysis without considering whether the same SPS tests were used in different theses or not.

\subsection{Validity and Reliability of the Study}

To conduct a valid and reliable study, first of all, an evaluation form was developed by one of the researchers of the present study so as to examine the SPS tests in the master's theses and doctoral dissertations. To provide the reliability of the form, three different researchers who are working in science education study area worked with the form independently to examine 10 different SPS tests found in the theses. After each independent examination, 98\% consensus were built between them. Therefore, a reliable evaluation form was created.

To achieve credibility and conformability (Guba, 1981; Lincoln \& Guba, 1985), the two researchers examined the SPS tests found in 116 theses independently and they built 95\% consensus on the examinations. In order to achieve transferability, the whole process which were followed by the researchers to conduct this meta-synthesis study were explained in detail and each step was shown explicitly. In addition, all the details of the selection process of the theses were represent explicitly. 


\section{FINDINGS}

SPS tests used in master's theses and doctoral dissertations were examined from the perspectives of originality. The findings represented in Table 3 point out that the $40.5 \%$ of the SPS tests used in theses were adaptations into Turkish; $37.1 \%$ of the SPS tests used in the theses were originally developed for corresponding theses; and $22.41 \%$ of the SPS tests used in the theses were revised versions of the adapted SPS tests to Turkish by considering the features of the sample, the aim of the corresponding study, etc. In Table 4, the findings were represented in detail.

Table 3. Derivatives of Science Process Skills Tests.

\begin{tabular}{lll}
\hline Derivatives & Frequency & Percentage (\%) \\
\hline Adapted & 47 & 40.5 \\
Originally Developed & 43 & 37.1 \\
Revised the Adapted Version & 26 & 22.41 \\
Total & 116 & 100 \\
\hline
\end{tabular}

In $16(47.05 \%)$ doctoral dissertations and $31(37.8 \%)$ master's theses, it was determined that an SPS test which was adapted to Turkish was used by the researchers of the corresponding studies. Additionally, it was observed that in 26 studies (20 master's theses and 6 doctoral dissertations), revised versions of the SPS tests according to the sample group of the corresponding studies were used. When graduate studies were examined, in 43 studies, it was seen that SPS tests were originally developed in each of those studies. It was found that among 34 doctoral dissertations, in 12 of them, SPS tests were originally developed; and, among 82 master's theses, in 31 of them, SPS tests were originally developed for each of the studies.

Table 4. Sources of Adapted SPS Tests.

\begin{tabular}{lcc}
\hline Source (Author, Year) & Frequency & Percentage (\%) \\
\hline $\begin{array}{l}\text { Test of Integrated Process Skills II (Burns, Okey \& } \\
\text { Wise, 1985) }\end{array}$ & 30 & 63.8 \\
$\begin{array}{l}\text { Science Process Test (Enger \& Yager, 1998) } \\
\text { The Science Process Assessment for Middle School }\end{array}$ & 8 & 17.02 \\
$\begin{array}{l}\text { Students } \\
\text { (Smith \& Welliver, 1994) }\end{array}$ & 6 & 14.2 \\
$\begin{array}{l}\text { Test of Integrated Process Skills (Tobin \& Capie, } \\
\text { 1981) }\end{array}$ & 2 & 4.25 \\
Total & 47 & 100 \\
\hline
\end{tabular}

In the present study, examinations were made to find the adapted SPS tests placed in the graduate theses. The result of the examinations is represented in Table 4 . When Table 4 is examined, it comes to the forefront that the adapted SPS test which was the most frequently used $(63.8 \%)$ in the master's theses and doctoral dissertations is the one developed by Burns et al. (1985). It was found that in 12 master's theses and 18 doctoral dissertations, these SPS tests were used. In the theses, it was also found that the adapted version of SPS tests developed by Enger and Yager (1998) and Smith and Welliver (1994) were used. In two master's theses, the SPS test developed by Tobin and Capie (1981) was used.

Within the scope of second questions of the present study, the question types of the SPS tests were examined. In Table 5, the question types of SPS tests are presented in terms of frequency and percentage. When the table is examined, it can be explicitly observed that approximately in all theses, SPS tests which contained questions in multiple-choice format were used (104, 
$89.6 \%$ ). On the other hand, it was seen that 8 SPS tests consisted of questions with open-ended and multiple-choice formats, two consisted of open-ended questions alone, and the other two contained questions with a mixed format.

Table 5. Distributions of science process skills tests according to question types.

\begin{tabular}{lcc}
\hline Question Type & Frequency & Percentage (\%) \\
\hline Multiple-choice & 104 & 89.6 \\
Open Ended + Multiple Choice & 8 & 6.90 \\
Open Ended & 2 & 1.72 \\
Mixed & 2 & 1.72 \\
Total & 116 & 100 \\
\hline
\end{tabular}

When SPS tests in the master's theses and doctoral dissertations examined separately, it was found that among 34 doctoral dissertations, 27 of them had SPS tests with multiple-choice question format, 5 of them had open-ended and multiple-choice question format and the other two doctoral dissertations had SPS tests with mixed type (multiple-choice, open-ended, matching, etc.) question format. Similarly, it was observed that, in the master's theses, SPS tests with multiple-choice question format were used more frequently when compared to SPS tests in doctoral theses. While among 82 master's theses, 77 of them had SPS tests with multiplechoice question format, 3 of them had open-ended and multiple-choice question format and the other two master's theses have SPS tests with open-ended questions, no SPS tests were found in the master's theses and doctoral dissertations whose questions type were mixed.

The findings regarding which process skills and with how many questions those skills were measured were obtained through analysis by using the evaluation form (Appendix 6.1) prepared for data analysis are represented in Table 6 . When Table 6 is examined, it is observed that there are 3800 questions in total in SPS tests used in the theses. In Table 7, SPSs typed in italic are the skills stated in the project of the Council of Higher Education/World Bank Development of National Education. Except for those skills, every process skill found in SPS tests has been included in Table 6. Every SPS test has been included for the examinations without considering whether those tests were used in other graduate theses of the sample. As a result of examinations, it was found that determining variables $(878,23.1 \%)$, formulating hypothesis $(612,16.1 \%)$, interpreting data $(474,12.47 \%)$, and making operational definition $(287,7.55 \%)$ were the most measured process skills. Additionally, it was observed that designing-making experiments $(184,4.84 \%)$, designing study $(156,4.1 \%)$, measuring $(138,3.63 \%)$, predicting $(123,3.23 \%)$, classifying $(115,3.02 \%)$, and observing $(104,2.73 \%)$ were other frequently measured process skills.

When the SPS tests were examined, it was found that making predictions $(6,0.15 \%)$ and decision making $(7,0.18 \%)$ are the least measured process skills. Additionally, presenting $(0.1 \%)$, guessing $(0.12 \%)$, describing $(0.15 \%)$, defining the problem $(0.23)$, asking questions $(0.3 \%)$, comparing $(0.31 \%)$, and using equipment $(0.39 \%)$ are other least measured process skills in SPS tests. Distinctly, in one of the SPS tests, it was found that socio-scientific issues $(1,0.02 \%)$ were stated as process skills. 
Table 6. Process skills measured in science process skills tests and the frequency of measurement.

\begin{tabular}{lcc}
\hline Process Skills & Frequency & Percentage (\%) \\
\hline Observing & 104 & 2.73 \\
Classifying & 115 & 3.02 \\
Measuring & 138 & 3.63 \\
Data Recording & 71 & 1.86 \\
Founding Space and Number Relationship & 74 & 1.94 \\
Making Predictions & 6 & 0.15 \\
Determining Variables & 878 & 23.1 \\
Interpreting Data & 474 & 12.47 \\
Inferring & 71 & 1.86 \\
Formulating Hypothesis & 612 & 16.1 \\
Using Data and Formulating Models & 103 & 2.71 \\
Designing-Making Experiments & 184 & 4.84 \\
Controlling Variables & 124 & 3.26 \\
Decision Making & 7 & 0.18 \\
Comparing & 12 & 0.31 \\
Predicting & 123 & 3.23 \\
Communicating & 38 & 1 \\
Using Equipment & 15 & 0.39 \\
Designing Study & 156 & 4.1 \\
Making Operational Definition & 287 & 7.55 \\
Deducing & 79 & 2.02 \\
Guessing & 5 & 0.12 \\
Presenting & 4 & 0.1 \\
Describing & 6 & 0.15 \\
Using Numbers & 21 & 0.53 \\
Associating & 22 & 0.56 \\
Asking Questions & 12 & 0.3 \\
Logical Thinking & 29 & 0.74 \\
Making Study & 20 & 0.51 \\
Defining the Problem & 9 & 0.23 \\
Socio-scientific Issues & 1 & 0.02 \\
Total & 3800 & 100 \\
\hline & & \\
& &
\end{tabular}

\section{DISCUSSION and CONCLUSION}

Within the scope of the study, the originality of the SPS tests was reviewed by the researchers. Among the SPS tests in master's theses and doctoral dissertations, it was revealed that to measure process skills of the students, an SPS test found the literature was used by the authors of the graduate studies. It was observed that the SPS test which was developed by Burns et al. (1985) and translated into Turkish by Geban et al. (1992) was used in master's theses and doctoral dissertations directly or through making revisions on the form according to the sample and the aim of the corresponding studies. For instance, in his study Aydoğdu (2006) pointed out that this test is for eighth graders and because his sample consisted of seventh graders, he used the adapted version of the tests by removing some questions. At that point, it can be emphasized that direct use of an SPS test found in the literature might not be always possible since the aim, sample, and the target group and the necessities of revising the SPS test retrieved from the literature might be a matter of discussion. On the other hand, among $36.12 \%$ of the 
SPS tests used in the graduate theses, it was found that an original test was developed for the corresponding study. When the procedure of the development of SPS tests was examined, it was realized that the tests were developed by considering the aim, the sample, the success level of the sample, the subject matter, etc. All in all, in nearly more than half of the theses, adapted version of the SPS tests were used instead of developing a new SPS tests.

One of the other aims of the study is to search for the question type of the SPS tests used in master's theses and doctoral dissertations. Within the scope of this aim, every question of the SPS tests was examined in detail. It was observed that most of the questions (89.91\%) of the SPS tests have a multiple-choice format. In addition, it is possible to figure out that SPS tests also have questions in mixed type question format or multiple-choice and open-ended question format at the same time although the number of those tests are less. It is emphasized that multiple-choice questions are objective and easy to score in which students are required to select the right choice among different alternatives (Tan, 2009). In this kind of test, students are restricted with the alternatives given to them and not free to answer the questions in their own ways (Tan et al., 2002). It is emphasized that multiple-choice tests measure the knowledge about facts, however, they do not provide students with the opportunity to regulate the knowledge they constitute and share the constituted knowledge (Yıldırım, 1983). Additionally, Tan (2009) emphasized that while multiple-choice tests can measure knowledge, comprehension and application behavior level, they are not enough to measure the behavior of creativity, producing idea and product, and synthesis. When SPSs are examined, it is possible to say that those skills have behavioral skills from knowledge to synthesis and creativity. Thus, the SPS tests which have only multiple-choice questions will not be enough to measure all the process skills. At that point, constructing SPS tests by using different type of questions comes to the forefront since by this way, SPSs and different type of behavior can be measured more easily.

It was aimed to find proportionally which process skills were measured in all of the SPS tests used in master's theses and doctoral dissertations. After examinations, it was revealed that causative and experimental SPSs were measured more frequently when compared to basic SPSs. It was pointed out that the most frequently measured SPSs were determining variables and formulating hypothesis. Kılıç et al. (2016) pointed out that determining variables is an important SPS since determining the variables of a study is an important factor which affects the research. In addition, hypothesis is a propositional statement which contains the knowledge about the effect of independent variables on the dependent variable (K1lıç et al., 2016) and thus, formulating hypothesis has an important place among SPSs. Although it has measured with fewer questions when compared to causative and experimental SPSs, there are still enough questions which measured basic SPSs. Çepni et al. (1997) emphasized that basic SPSs are useful in developing higher-order SPSs in students and pointed out the importance of teaching students the basic SPSs to teach them complex SPSs. In the present study, it was found that observing, classifying, and measuring are the process skills which are measured frequently through SPS tests.

SPSs are emphasized as the basic skills which are used to constitute scientific knowledge by using scientific way (Tan \& Temiz, 2003) and make science learning easier and students active during lessons and help them to take the the responsibilities of their own learning (Çepni et al., 1997). From these perspectives, the importance of developing SPSs in students, deciding whether they gain those skills or not and the necessity of valid and reliable SPS tests to measure the outcomes come into prominence.

As a result of the examination, it was revealed that process skills were generally measured by using multiple-choice questions in the SPS tests. At that point, the requirement of a new SPS 
test in which each process skill was measured with appropriate question type comes to the forefront and preparing and using a new SPS test is suggested by the researchers.

Thanks to this study, it was observed that 21 st century skills have been measured less frequently by existing SPS tests. Among the SPSs, only logical thinking and defining problem can be shown as 21 st century skills which were used in the tests. However, the frequency of measuring those skills is very rare. At that point, constructing a new SPS test by using items which measure 21 st century skills more frequently can be pointed out as another suggestion.

\section{Acknowledgments}

This study was presented at ERPA International Congress which was held in 2018 in İstanbul.

\section{Declaration of Conflicting Interests and Ethics}

The authors declare no conflict of interest. This research study complies with research publishing ethics. The scientific and legal responsibility for manuscripts published in IJATE belongs to the authors.

\section{Authorship Contribution Statement}

Okan Sibic and Burcin Acar Sesen work collaboratively in the process of Investigation, Sampling, Examiniton, Writing of the Manuscripts. Burçin Acar Şeşen also supervised the writing process.

\section{Orcid}

Okan Sibic (D) https://orcid.org/0000-0001-7241-274X

Burcin Acar Sesen (D) https://orcid.org/0000-0002-1585-0441

\section{REFERENCES}

AAAS. (1993). Benchmarks for science literacy, a project 2061 report. Oxford University Press.

Anagün, Ş.S., \& Yaşar, Ş. (2009). Developing scientific process skills at science and technology course in fifth grade students. Illkögretim Online, 8(3), 844-865.

Aslan, S., Kılıç, H.E., \& Kılıç, D. (2016). Bilimsel süreç becerileri [Science Process Skills]. Pegem Akademi.

Bair, C. R. (1999, November). Meta-synthesis. The annual meeting of the Association for the Study of Higher Education, San Antonio, TX.

Burns, J.C., Okey, J.R., \& Wise, K.C. (1985). Development of an integrated process skill test: TIPS II. Journal of Research in Science Teaching, 22(2), 169-177.

Charlesworth, R., \& Lind, K.K. (2012). Math and science for young children. Wadsworth Cengage Learning.

Çepni, S., Ayas, A., Johnson, D., \& Turgut, M.F. (1997). Physics teaching. YÖK/Dünya Bankası Milli Eğitimi Geliștirme Projesi, Hizmet Öncesi Öğretmen Eğitimi.

Daşdemir, İ. (2012). The effect of using of animation on students? academic achievement, retention of learned knowledge and scientific process skills [Unpublished doctoral dissertation]. Atatürk University.

Demirörs, F. (2018). Effect of the 7e learning model enriched with self regulated cognitive strategies on the student's achievment in the subject matter energy and on their science process skills [Unpublished doctoral dissertation]. Hacettepe University.

Enger, S.K., \& Yager, R.E. (1998). The Iowa assessment handbook. Iowa University Science Education Center.

Erkol, S., \& Ugulu, I. (2014). Examining biology teachers candidates' scientific process skill levels and comparing these levels in terms of various variables. Procedia-Social and Behavioral Sciences, 116, 4742-4747. 
Geban, Ö., Aşkar, P., \& Özkan, İ. (1992). Effects of computer simulations and problem-solving approaches on high school students. The Journal of Educational Research, 86(1), 5-10.

Guba, E.G. (1981). Criteria for assessing the trustworthiness of naturalistic inquiries. ECTJ, 29(2), 75-91.

Gültekin, B.G. (2018). Examination of the impacts of activity based on science process skills on the problem solving abilities of students at 4th grade in primary school. [Unpublished master's thesis]. Karadeniz Technical University.

Kazeni, M.M.M. (2005). Development and validation of a test integrated science process skills for the further education and training learners [Unpublished master's thesis]. University of Pretoria, South Africa.

Lincoln, Y.S., \& Guba, E.G. (1985). Establishing trustworthiness. Naturalistic inquiry, 289(331), 289-327.

Ministry of National Education. (2018). Elementary and middle school (3, 4, 5, 6, 7, and 8th grades) science curriculum. Board of Education and Training.

Ongowo, R.O., \& Indoshi, F.C. (2013). Science process skills in the Kenya certificate of secondary education biology practical examinations. Procedia-Social and Behavioral Sciences, 4(11), 713-717.

Ostlund, K.L. (1992). Science process skills assesing hands-on student performance. AddisonWesley.

Rezba, R.J., Sprague, C.R., McDonnough, J.T., \& Matkins, J.J. (2007). Learning and assessing science process skills. Kendall/Hunt Publishing Company.

Smith, K.A., \& Welliver, P.W. (1994). Science process assessments for elementary and middle school students. Smith and Welliver Educational Services. http://www.scienceprocesste sts.com/

Tan, Ş. (2009). Öğretimde ölçme ve değerlendirme KPSS el kitabı (3rd ed.) [Assessment and evaluation in Teaching KPSS handbook (3 ${ }^{\text {rd }}$ ed.]. Pegem Akademi Yayıncilık.

Tan, Ş., Kayabaş1, Y., \& Erdoğan, A. (2002). Planning and evaluation of teaching. Anı Yayınc1lik.

Tan, M., \& Temiz, B.K. (2003). Fen öğretiminde bilimsel süreç becerilerinin yeri ve önemi [The importance and role of the science process skills in science teaching]. Pamukkale Üniversitesi Ĕ̈itim Fakültesi Dergisi, 13(13), 89-101.

Tatar, N. (2006). The effect of inquiry-based learning approaches in the education of science in primary school on the science process skills, academic achivement and attitude. [Unpublished doctoral dissertation]. Gazi University, Ankara.

Tobin, K.G., \& Capie, W. (1982). Development and validation of a group test of integrated science processes. Journal of research in Science Teaching, 19(2), 133-141.

Walsh, D., \& Downe, S. (2005). Meta-synthesis method for qualitative research: a literature review. Journal of Advanced Nursing, 50(2), 204-211.

Yıldırım, C. (1983). Eğitimde ölçme ve değerlendirme [Measurement and evaluation in education]. ÖSYM Ĕ̈itim Yayınları 


\section{APPENDIX}

Evaluation Form for Science Process Skills Tests.

Measured Science Process Skills and Question Numbers

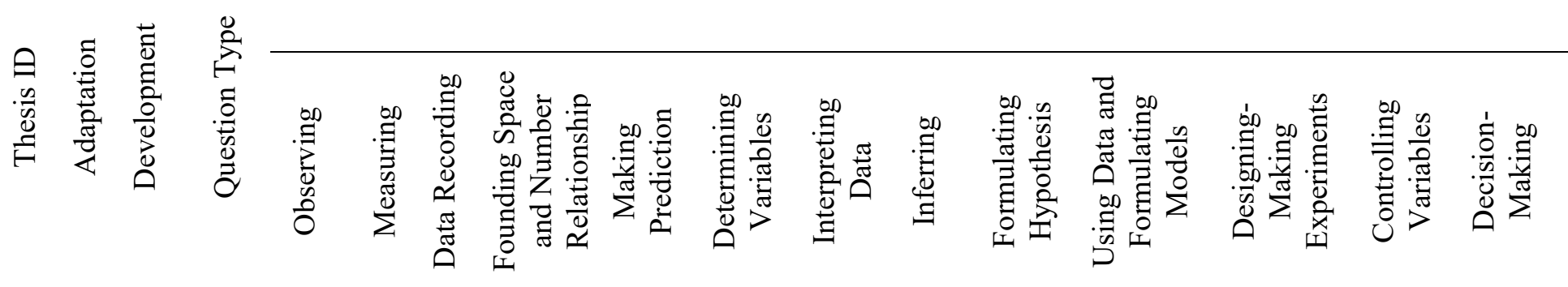


Table 7. The reviewed master's theses and doctoral dissertations.

\begin{tabular}{|c|c|}
\hline $\mathrm{No}$ & Percentage $(\%)$ \\
\hline 1 & $\begin{array}{l}\text { Acar, E.N. (2011). The effect of project-based learning on scientific skill processes and } \\
\text { attitudes towards biology of science teacher candidates. [Unpublished master's thesis]. } \\
\text { Çanakkale Onsekiz Mart University. }\end{array}$ \\
\hline 2 & $\begin{array}{l}\text { Akar, Ü. (2007). The relationship between student teachers' scientific process skills and } \\
\text { critical thinking. [Unpublished master's thesis]. Afyon Kocatepe University. }\end{array}$ \\
\hline 3 & $\begin{array}{l}\text { Aktamiş, H. (2007). The effects of scientific process skills on scientific creativity: the example } \\
\text { of primary school seventh grade physics. [Unpublished doctoral dissertation]. Dokuz Eylül } \\
\text { University. }\end{array}$ \\
\hline 4 & $\begin{array}{l}\text { Aktaş, S. (2016). The effect of middle school 6th, 7th and 8th science teaching curriculum } \\
\text { programs on the students' cognitive styles, emotional intelligent, science process skills and } \\
\text { academic achievement. [Unpublished master's thesis]. Mustafa Kemal University. }\end{array}$ \\
\hline 5 & $\begin{array}{l}\text { Altunsoy, S. (2008). The effect of the inquiry-based learning approach on students? science } \\
\text { process skills, academic achievements and attitudes in secondary biology teaching. } \\
\text { [Unpublished master's thesis]. Selçuk University. }\end{array}$ \\
\hline 6 & $\begin{array}{l}\text { Arslan, A. (2013). The examination of pre-service teachers' science process skills and } \\
\text { conceptual change in inquiry and model based inquiry environment. [Unpublished master's } \\
\text { thesis]. Marmara University. }\end{array}$ \\
\hline 7 & $\begin{array}{l}\text { Aydinl1, E. (2007). Evaluation of science process skill study on the } 6,7 \text { and } 8 \text {. Students. } \\
\text { [Unpublished master's thesis]. Gazi University. }\end{array}$ \\
\hline 8 & $\begin{array}{l}\text { Aydoğdu, B. (2006). Identification of variables effecting science process skills in primary } \\
\text { science and technology course. [Unpublished master's thesis]. Dokuz Eylül University. }\end{array}$ \\
\hline 9 & $\begin{array}{l}\text { Aydoğdu, B. (2009). The effects of different laboratory techniques on students' science } \\
\text { process skills, views towards nature of science, attitudes towards laboratory and learning } \\
\text { approaches in science and technology course. [Unpublished doctoral dissertation]. Dokuz } \\
\text { Eylül University. }\end{array}$ \\
\hline 10 & $\begin{array}{l}\text { Bahadır, H. (2007). The effect of elementary science education based on scientific method } \\
\text { process on science process skills, attitude, academic achievement and retention. } \\
\text { [Unpublished master's thesis]. Hacettepe University. }\end{array}$ \\
\hline 11 & $\begin{array}{l}\text { Başdaş, E. (2007). The effect of hands-on science learning method in the education of science } \\
\text { in primary school on the science process skills, academic achievement and motivation. } \\
\text { [Unpublished master's thesis]. Celal Bayar University. }\end{array}$ \\
\hline 12 & $\begin{array}{l}\text { Bayrak, B. (2011). The effect of problem based instruction supported with web technology on } \\
\text { the academic achievement, conceptual understanding, scientific process skills of 8th grade } \\
\text { students in science and technology instruction: Acid base sample. [Unpublished doctoral } \\
\text { dissertation]. Marmara University. }\end{array}$ \\
\hline 13 & $\begin{array}{l}\text { Bilen, K. (2009). The effects of a laboratory instruction designed based on the 'predict- } \\
\text { observation-explain' strategy on preservice teachers? on conceptual achievement, science } \\
\text { process skills, attitudes and views about the nature of science. [Unpublished doctoral } \\
\text { dissertation]. Gazi University. }\end{array}$ \\
\hline 14 & $\begin{array}{l}\text { Birinci, E. (2008). The effect of using project-based learning in the adaptation and } \\
\text { development of materials on teacher candidates? critical thinking, creative thinking and } \\
\text { scientific-process skills. [Unpublished master's thesis]. Karaelmas University. }\end{array}$ \\
\hline 15 & $\begin{array}{l}\text { Bodur, Z. (2015). The effect of outdoor class activities in the solar system and beyond unit on } \\
\text { seventh grade students' academic achievements, scientific process abilities and motivation. } \\
\text { [Unpublished master's thesis]. Marmara University. }\end{array}$ \\
\hline 16 & $\begin{array}{l}\text { Bozkurt, E. (2014). The effect of engineering design based science instruction on science } \\
\text { teacher candidates' decision making skills, science process skills and perceptions about the } \\
\text { process. [Unpublished doctoral dissertation]. Gazi University. }\end{array}$ \\
\hline 17 & $\begin{array}{l}\text { Cin, M. (2013). Effects of concept cartoon activities based-argumentation method on } \\
\text { students' conceptual understanding levels and scientific process skills. [Unpublished master's } \\
\text { thesis]. Dokuz Eylül University. }\end{array}$ \\
\hline
\end{tabular}


Çakar, E. (2008). Determination of the level of students' achievement of the science process skills acquisition of 5th-grade science and technology program. [Unpublished master's thesis]. Süleyman Demirel University.

Çelik, S. (2009). The influence of project based learning approach on pre-service science teachers? conceptions of the nature of science and technology and scientific process skills. [Unpublished doctoral dissertation]. Atatürk University.

Çelik, K. (2012). The effect of inquiry based learning method for the teaching of reproduction, growth and development in the living things unit on the students' academic achievements, science process skills and attitudes toward science and technology course. [Unpublished master's thesis]. Dokuz Eylül University.

Çelik, P. (2013). The effect of problem based learning on pre-service teachers' physics course

21 achievement, learning approaches and science process skills. [Unpublished doctoral dissertation]. Dokuz Eylül University.

Çetin, A. (2013). Mode-method interaction: The effects of inquiry vs. expository and blended

$22 v$ v. face-to-face instruction on 9th grade students' achievement in, science process skills in and attitudes towards physics. [Unpublished doctoral dissertation]. Middle East Technical University.

Çınar, B. (2016). The effect of enriching science and technology education by using stories

23 which include historical process of scientific improvement on attitudes to science, the image of scientist, skills of scientific process and the academic achievement. [Unpublished master's thesis]. Sakarya University.

Çoban, G.Ü. (2009). The effects of model based science education on students' conceptual understanding, science process skills, understanding of scientific knowledge and its domain of existence: The sample of 7 th grade unit of light. [Unpublished doctoral dissertation]. Dokuz Eylül University.

Çümen, V. (2018). The analysis effect of GEMS based learning program's on 6th grade

25 student's achievement about concept of densities, conceptual changes and scientific progress. [Unpublished master's thesis]. Uşak University.

Daşdemir, İ. (2012). The effect of using of animation on students? academic achievement,

26 retention of learned knowledge and scientific process skills. [Unpublished doctoral dissertation]. Atatürk University.

27 Demir, M. (2007). The factors affecting the pre-service primary teachers' adequacies on science process skills. [Unpublished doctoral dissertation]. Gazi University.

Demirçal1, S. (2016). The effects of model based science education on students' academic

28 achievement,scientific process skills and mental model development: the sample of 7 th grade unit of "The Solar System and Beyond: The Puzzle of Space". [Unpublished doctoral dissertation]. Gazi University.

Demirezen, S. (2010). The effect of 7 e model to students achievement, development of scientific process skills, conceptual achievement and retention levels in electrical circuits subject. [Unpublished doctoral dissertation]. Gazi University.

30 Duran, M. (2008). The effects of scientific process skills in science teaching on students' attitudes towards science. [Unpublished master's thesis]. Muğla Sitka Koçman University.

31 Elbistanl1, A. (2012). Investigation of the effect of problem based learning approach on the equilibrium subject. [Unpublished master's thesis]. Mustafa Kemal University.

32 Elmac1, S. (2015). Investigation of class teachers' process skills in scope of a number of variables. [Unpublished master's thesis]. Dumlupınar University.

Ercan Ö.T. (2010). İlkögretim yedinci sinif fen ve teknoloji dersinde 5E ögrrenme halkast ve

33 bilimsel süreç becerileri doğrultusunda uygulanan etkinliklerin, öğrencilerin akademik başarılarl, bilimsel süreç becerileri ve derse yönelik tutumlarına etkisi. [Unpublished doctoral dissertation]. Ege University.

Erdoğan, M. (2010). Effect of experiment techniques of group and demonstration to students' scientific process abilities, achievement and the ability of recalling. [Unpublished master's thesis]. Selçuk University. 
Erentay, N. (2013). The effect of nature based outdoor activities upon the science knowledge

35 levels, scientific process skills and attitudes towards environment of the fifth grade students. [Unpublished master's thesis]. Akdeniz University.

36 Eroğlu, G. (2015). Determination of science process skills of teacher candidates in the field of science. [Unpublished master's thesis]. Gazi University.

Ertek, Y. (2014). Investigation of the relationship between scientific process skills and problem solving skills stated in the physics curriculum. [Unpublished master's thesis]. Ankara University.

38 Erten, N. (2013). An investigation of primary teacher's science process skills in terms of some variables. [Unpublished master's thesis]. Afyon Kocatepe University.

Gençoğlan, D.M. (2017). The effects of argumentation based science learning (ABSL)

39 approach based on authentic case studies on the success, attitude and scientific process skills of 8th grade students in the acids and bases lesson. [Unpublished master's thesis]. Kahramanmaraş Sütçü İmam University.

Gök, G. (2014). The effect of 7e learning cycle instruction on 6th grade students' conceptual

40 understanding of human body systems, self-regulation, scientific epistemological beliefs, and science process skills. [Unpublished doctoral dissertation]. Middle East Technical University.

Güçlüer, E. (2012). The effect on success, attitude and scientific process skills of the use of 41 scientific literacy developing activities in the unit named "systems of our body" in science and technology course. [Unpublished doctoral dissertation]. Dokuz Eylül University.

Guden, C. (2015). Examining secondary school students' cognitive process skills and attitudes towards science and technology course (Çanakkale sample). [Unpublished master's thesis]. Çanakkale Onsekiz Mart University.

Gülay, A. (2012). Effect of self regulated learning on 5th grade students' academic

43 achievement and scientific process skills. [Unpublished master's thesis]. Recep Tayyip Erdoğan University.

Güler, Z. (2010). The relationship among elementary students' test scores of level

44 determination exam, course achievements, science processing skills and logical thinking skills. [Unpublished master's thesis]. Abant İzzet Baysal University.

Güler, B. (2013). The effect of blended learning method on preservice elementary science and

45 technology teachers' attitudes toward technology and self-regulation and science process skills. [Unpublished master's thesis]. Dokuz Eylül University.

Gültekin, Z. (2009). The effect of project based learning applications on the students' views

46 about the nature of science, science process skills and the attitude of students in science education. [Unpublished master's thesis]. Marmara University.

Güney, T. (2015). The effect of simulation aided science laboratory applications based on inquiry on science process skill: An example of the force and motion unit. [Unpublished master's thesis]. Kırıkkale University.

Güngör, S.N. (2016). The influence of teaching biological subjects and concepts to pre-

48 science teachers through predict-observe-explain (POE) method on achievement, permanence, and scientific process skills. [Unpublished doctoral dissertation]. Uludağ University.

49 Hazır, A. (2006). The fifth-grade primary school students' the level of acquisition of science process skills. [Unpublished master's thesis]. Afyon Kocatepe University.

50 İpek, Y. (2010). Investigating scientific process skills development at science and technology course. [Unpublished master's thesis]. Yüzüncü Y1l University.

51 Kandemir, E.M. (2011). Determination of the level of teachers' understanding of integrated scientific process skills. [Unpublished master's thesis]. Ege University.

Kanl1, U. (2007). The effects of a laboratory based on the $7 e$ model with verification

52 laboratory approach on students? development of science process skills and conceptual achievement. [Unpublished doctoral dissertation]. Gazi University. 
Kaplan, M. (2016). The effect of the differentiated method on seventh graders' conceptual 53 learning, scientific process skills and academic achievement in the science unit "Force and movement". [Unpublished master's thesis]. Dokuz Eylül University.

54 Kara, E. (2017). Research of the effects of science education based on predict-observe explain strategy on 5th grade middle school students' science process skills and success. [Unpublished master's thesis]. Marmara University.

Karaca, D. (2011). Effect of the use of science writing heuristic (SWH) in General Physics

55 Laboratory-I lesson on teacher candidates' achievement and scientific process skills. [Unpublished master's thesis]. Mehmet Akif Ersoy University.

Karademir, E. (2009). The effect of computer supported education towards students'

56 academic success levels, scientific process skills and attitudes in the electric unit of science and technology lesson. [Unpublished master's thesis]. Eskişehir Osmangazi University.

Karapınar, A. (2016). The impact of inquiry-based learning environment on scientific process

57 skills, inquiry skills and scientific reasoning skills of pre-service teachers. [Unpublished master's thesis]. Celal Bayar University.

58 Karar, E.E. (2011). The study of science process skills of eighth graders with regard to several variant. [Unpublished master's thesis]. Adnan Menderes University.

Karatay, R. (2012). Developing a science process skills test regarding the units of the 7th

59 grade Science and Technology education program. [Unpublished master's thesis]. Çanakkale Onsekiz Mart University.

Karatekin, P. (2012). Effect of candidate teachers of Science and Technology at biology

60 laboratories on TGA method on students? success, attitude and scientific process abilities. [Unpublished master's thesis]. Celal Bayar University.

Karsl1, F. (2011). The effect of enriched laboratory guide materials on improving science process skills and conceptual change of prospective science teachers. [Unpublished doctoral dissertation]. Karadeniz Technical University.

Kartal Taşoğlu, A. (2009). The effect of problem based learning on students? Achievements,

62 scientific process skills and attitudes towards problem solving in physics education. [Unpublished master's thesis]. Dokuz Eylül University.

63 Keçeci, G. (2014). The effects of inquiry-based science teaching on students' science process skills and attitudes. [Unpublished doctoral dissertation]. Furat University.

Keskinkılıç, G. (2010). The effect of reflective thinking based learning activities in 7th class

64 science and technology lesson on the students' achievements and their scientific process skills. [Unpublished doctoral dissertation]. Selçuk University.

K1liç, A.S. (2015). The impact of the activities prepared through the integration of science

65 and mathematics on the critical thinking and science process skills of the gifted 6th grade secondary school students. [Unpublished doctoral dissertation]. Gazi University.

Kırıktaş, H. (2014). The effect of inquiry based science teaching on pre-servive science

66 teachers' academic achievement, science process skills and attitudes towards biology laboratory practice. [Unpublished master's thesis]. Dokuz Eylül University.

Kirllmazkaya, G. (2014). The effects of web based inquiry science teaching development on preservice teachers concept learning and scientific process skills. [Unpublished doctoral dissertation]. Firat University.

Kirtak Ad, V.N. (2016). The effect of full studio model on pre-service primary science teachers' conceptual understanding, social emotional learning, inquiry and science process skills: An example of fluid mechanics. [Unpublished doctoral dissertation]. Balıkesir University.

Kocagül, M. (2013). The effect of inquiry based professional development activities on

69 elementary Science and Technology teachers science process skills and self-efficacy and inquiry based teaching beliefs. [Unpublished master's thesis]. Dokuz Eylül University.

Korucuoğlu, P. (2008). Evaluation of correlation between scientific process skills' usage level

70 of physics teacher candidates with the attitudes towards physics, gender, class level and high school type which they graduated from. [Unpublished master's thesis]. Dokuz Eylül University. 
71 Kozcu Çakır, N. (2013). The science process skills of pre-service science teachers' qualitative and quantitative analysis. [Unpublished doctoral dissertation]. Gazi University.

72 Köksal, E.A. (2008). The acquisition of science process skills through guided (teacherdirected) inquiry. [Unpublished doctoral dissertation]. Middle East Technical University.

Kula, G. (2011). The effect of pre-school education on 1st, 2nd and 3rd grade high school

73 students' science process skills: the sample of Polatl district. [Unpublished master's thesis]. Gazi University.

Kula, Ş.G. (2009). The effect of inquiry-based science learning on the students' science

74 process skills, achievement, concept learning and attitude. [Unpublished master's thesis]. Marmara University.

Kurtuluş, N. (2012). The effect of instructional applications based on creative thinking on

75 scientific creativity, scientific process skills and academic achievement. [Unpublished master's thesis]. Karadeniz Technical University.

Meşeci, B. (2013). The gaining of scientific skills and the effectiveness the learning process

76 of the unit particulated structure of the matter. [Unpublished master's thesis]. Amasya University.

Mutlu, S. (2012). The effects of science and technology education based on scientific process

77 skills on scientific process skills, motivation, attitude, and achievement of elementary school students. [Unpublished master's thesis]. Trakya University.

78 Önol, M. (2013). The impact of creative problem solving activities on scientific process skills and success. [Unpublished master's thesis]. Balıkesir University.

Özahioğlu, B. (2012). The effect of project-based learning in Science and Technology at

79 primary school on scientific process skills, success and attitude. [Unpublished master's thesis]. Çanakkale Onsekiz Mart University.

Ozdemir, H. (2009). The level of having scientific process skills of 5 th class primary school's students (Afyonkarahisar sample). [Unpublished master's thesis]. Afyon Kocatepe University.

Özdemir, G. (2017). An action research about enriched curriculum towards the contribution

81 to scientific process skills and achievement for gifted students. [Unpublished master's thesis]. Hacettepe University.

Özdoğru, E. (20139. The effect of Lego programme based science and technology education

82 on the students' academic achievement, science process skills and their attitudes toward Science and Technology course for physical facts learning field. [Unpublished master's thesis]. Dokuz Eylül University.

Özer, D.Z. (2011). The effect of project based learning approach on both the academic

83 achievement and the development of science process skills of prospective teachers of science education department towards biology lesson. [Unpublished doctoral dissertation]. Uludağ University.

Özkan, D.O. (2011). The effect of using V-diagrams in 'living things and energy relations'

84 unit's experiments in eighth grade science and technology lessons on students' achievements, science process skills and attitudes. [Unpublished master's thesis]. Gazi University.

85 Öztürk, N. (2008). Primary seventh-grade students' level of gaining science process skills in science and technology course. [Unpublished master's thesis]. Eskişehir Osmangazi University.

Öztürk, Ç. (2008). The effects of 5e model on the scientific process skills, academic

86 achievement and attitude towards the geography course. [Unpublished doctoral dissertation]. Gazi University.

Öztürk, A. (2014). The effects of curricula at Mevlana Public and Science Center on students'

87 science process skills and attitudes toward science. [Unpublished master's thesis]. Ege University.

Parim, G. (2009). The effects of inquiry on the concept learning, achievement and

88 development of scientific process skills of 8th grade students as related to photosynthesis and respiration. [Unpublished doctoral dissertation]. Marmara University. 
Recepoğlu, B. (2012). The effect of the open- ended experimental technique on science 89 process skills, scholar success and attitude toward biology. [Unpublished master's thesis]. Çanakkale Onsekiz Mart University.

90 Sabir, A. (2016). The investigate of affecting factors on the science process skills of 4th and 5 th grade students. [Unpublished master's thesis]. Mustafa Kemal University.

Savaş, E. (2011). Effect of the science process skills laboratory approach supported with peer

91 instruction on science process skills of teacher candidates. [Unpublished master's thesis]. Balikesir University.

Sedef, A. (2012). The effect of creative drama activities on elementary school seventh grade

92 students scientific process skills, scientific creativity and self-regulation. [Unpublished master's thesis]. Pamukkale University.

Serin, G. (2009). The effect of problem based learning instruction on 7th grade students'

93 science achievement, attitude toward science and scientific process skills. [Unpublished doctoral dissertation]. Middle East Technical University.

Sevinç, E. (2008). The effects of the $5 E$ model on the students' conceptual understanding, the

94 development of their scientific process skills and their attitude in the organic chemistry laboratory course. [Unpublished master's thesis]. Gazi University.

Şahbaz, Ö. (2010). The effects of different methods on students' science process skills,

95 problem solving skills, academic achievements and retentions in primary school fifth grade science and technology lessons. [Unpublished doctoral dissertation]. Dokuz Eylül University.

96 Şardağ, M. (2013). A study of test development to measure science process skills of 8th grade students. [Unpublished master's thesis]. Balıkesir University.

97 Şen, A.Z. (2011). Examining 12th grade high school students' science process skills levels. [Unpublished master's thesis]. Balıkesir University.

Şencan, D. (2013). The effects of real-world problems on the 7th grade students' scientific

98 process abilities, academic achievement and scientific literacy: Force and motion. [Unpublished master's thesis]. Marmara University.

Tavukçu, F. (2008). The effect of computer-assisted learning environment in science

99 education on the success, science process skills and attitudes towards computer use of students. [Unpublished master's thesis]. Karaelmas University.

Temiz, B.K. (2001). Investigation of the appropriateness of the 9 th grade physics curriculum

100 on the progression of the students scientific process skills. [Unpublished master's thesis]. Gazi University.

101 Temiz, K.B. (2007). Assessing Science Process Skills in Physics Teaching. [Unpublished doctoral dissertation]. Gazi University.

Tezcan, G. (2011). Developing a science process skills test regarding the units of the 6th

102 grade science and technology education program. [Unpublished master's thesis]. Çanakkale Onsekiz Mart University.

Topkara, F. (2010). Anatolian high school students, high school of science and net for the

103 entrance examination, their attitudes towards physics course, the relationship between academic achievement and the scientific process skills: the case of district in Ankara, Elmadağ. [Unpublished master's thesis]. Gazi University.

Toprak, F. (2011). The effects of $3 E$ and $5 E$ teaching models practiced in general chemistry laboratory of science education on students' academic success scientific process skills and their attitude to the course. [Unpublished master's thesis]. Ondokuz Mayis University. Türker, E. (2011). To investigate how scientific process skills approach based on model using

105 affect the students? Success, development of process skills and motivations. [Unpublished master's thesis]. Karadeniz Technical University.

Usta Gezer, S. (2014). The effects of reflective inquiry based general biology laboratory activities' on preservice science teachers' laboratory self-efficacy perceptions, critical thinking tendencies and scientific process skills. [Unpublished doctoral dissertation]. Marmara University. 
Uzun, F. (2013). The effect of the general physics-I laboratory course based on context-based

107 approach on preservice science teachers' achievement, scientific process skills, motivation and recall. [Unpublished master's thesis]. Marmara University.

108 Unald, Ö. (2012). Effect of the scientific process skills-based science education on students science attitudes and scientific process skills. [Unpublished master's thesis]. Ankara University.

109 Yalçın, T. (2014). The effect of inquiry based learning method on students' scientific process skills and conceptual understanding. [Unpublished master's thesis]. Dokuz Eylül University. Yaprakdal, A.B. (2013). The effect of learning objects design on the critical and creative

110 thinking capacities and science process skills of prospective teachers. [Unpublished doctoral dissertation]. Marmara University.

Yavuz Şahin, S. (2009). The contribution of development science process skills that been

111 consist at implementation process in the unit of human and environment grade 7 in the primary science and technology curriculum. [Unpublished master's thesis]. Balikesir University.

112 Yildırım, M. (2011). Interrelationships of scientific process skills. [Unpublished master's thesis]. Atatürk University.

Yıldırım, A. (2012). Effect of guided inquiry experiments on the acquisition of science process

113 skills, achievement and differentiation of conceptual structure. [Unpublished master's thesis]. Middle East Technical University.

Y1ld1z, N. (2010). The effect of experiment applications on the success, attitude and scientific

114 process abilities of the students in the solution of the learning scenarios based on problems in science education. [Unpublished master's thesis]. Marmara University.

115 Y1lmaz, F.N. (2015). The effect of project based learning method on the 6th graders achievement and scientific process skills in science education. [Unpublished master's thesis]. Pamukkale University.

Yırtıc1, Z. (2014). Impact of optional courses of scientific application on students' scientific

116 process skills and motivations towards science. [Unpublished master's thesis]. Gazi University. 